\title{
The Chemical Fractions and Leaching of Heavy Metals in Ash from Medical Waste Incineration using Two Different Sequential Extraction Procedures
}

\begin{abstract}
LIDIA KIM, GINA ALINA CATRINA (TRAISTARU)*, BOGDAN STANESCU, LUOANA FLORENTINA PASCU, TANASE GHEORGHITA, DANIEL MANOLACHE

National Research and Development Institute for Industrial Ecology ECOIND Bucharest, 71-73 Drumul Podul Dambovitei Street, 060652, Bucharest, Romania

The paper presents the chemical fractions and leaching of the heavy metals in the bottom and filter ashes from the incineration of medical waste by two comparative methods of sequential extraction and by Toxicity Characteristic Leaching Procedure test (TCLP). The BCR classic method has higher extraction percentages than proposed modified BCR method. In both ashes, the metals are predominantly bounded in F1 (exchangeable) and F2 (iron and manganese oxides) fractions. Due to the high content of metals in filter ash, representing over $17,000 \mathrm{mg} / \mathrm{kg}$ dry matter for $\mathrm{Zn}, 7,000 \mathrm{mg} / \mathrm{kg}$ dry matter for $\mathrm{Pb}$, and 1,400 mg/kg dry matter for $\mathrm{Cr}$ and $\mathrm{Cu}$ in $\mathrm{F} 1$ and $\mathrm{F} 2$ fractions, a special attention should be given to the management and storage of this waste.
\end{abstract}

Keywords: sequential extraction, heavy metals, ash, medical waste

The incineration as a method of disposal of dangerous medical waste has the advantage that through this process reduces both the volume and the mass of waste as well as the decomposition of organic compounds. At the temperature of $800-1000^{\circ} \mathrm{C}$, the ash resulted from the incineration of medical waste (about $25 \%$ of the total waste mass) is presented as two residuals, called bottom ash and filter ash. The ash formed from coarse particles enriched with heavy metals, salts and other pollutants is collected in the recovery area (bottom ash). The transfer of metals to filter ash is favored by the increased temperature in the incinerator, which leads to the growth of dust particles enriched with heavy metals, chlorine and sulfur from the combustion gases [1]. It is known that metals are not biodegradable, their dispersion from ash in the air, soil and surface water components lead to significant environmental pollution [2, 3].

To know the content of metals and the chemical fractions in which the metals can be found in ash it is a very important aspect. Therefore, on the basis of metal fractions, it can be estimated both the danger and toxic potential induced on the environment, as well as to obtain the information for future decisions regarding the ash management [4].

The sequential extraction is an analytical multi-stage extraction method used to quantify some metallic fractions associated with the solid phase. This method is applied using specific solutions for extraction, the method being performed on various environmental matrices. The sequential extraction was first introduced by Tessier et al. in 1979 for the evaluation of metallic fractions from sediments [5]. Subsequently, it was extended to quantify the metallic fractions in soils, sludge and wastes [6-12]. The mostcommon sequential extraction methods reported in the literature are Tessier and BCR methods (Commission of the European Communities Bureau of Reference) [1315].

Over the past decade, as a result of the increase amount of dangerous waste generated each year, it is necessary to assess the metallic fractions of wastes in order to estimate the bioavailability for the environment. Although these methods have been successfully applied to sediments, soils and sludge, in the case of wastes considered as complex matrices, it is necessary to adapt the sequential extraction methods and optimize some working parameters. For example, the metallic compounds present in the sample, particle size and $\mathrm{pH}$, characteristics that have been found to be similar in other environmental components, in waste and ash can vary from one matrix to another. Thus, a series of studies have been carried out on the evaluation of metals by sequential extraction methods adapted to ash resulting from the incineration of municipal, medical and industrial wastes [16-19].

The paper presents the evaluation and characterization of the metal fractions in bottom and filter ashes from the medical waste incineration using two different sequential extraction methods: classic BCR method and modified BCR method using ultrasonic extraction [20]. The toxicity of metals in the leaching process was assess after applying TCLP test [21].

\section{Experimental part}

Ash sampling

The ashes samples were taken from a medical waste incineration, ash generated being both from medical and veterinary activities. In order to obtain a representative sample, the samples were taken from two different batches and analyzed separately. The identification data of the samples are shown in table 1.

The ash samples from incinerated medical waste were dried at room temperature, homogenized and then sieved in a Fritsch Analysette 3 Spartan Vibratory Sieve Shaker. In

Table 1

SAMPLESDESCRIPTION

\begin{tabular}{|c|c|c|}
\hline Batch & Sample code & Samples description \\
\hline \multirow{2}{*}{1} & BA1 & Bottom ash from batch 1 \\
\cline { 2 - 3 } & FA1 & Filter ash from batch 1 \\
\hline \multirow{2}{*}{2} & BA2 & Bottom ash from batch 2 \\
\cline { 2 - 3 } & FA2 & Filter ash from batch 2 \\
\hline
\end{tabular}




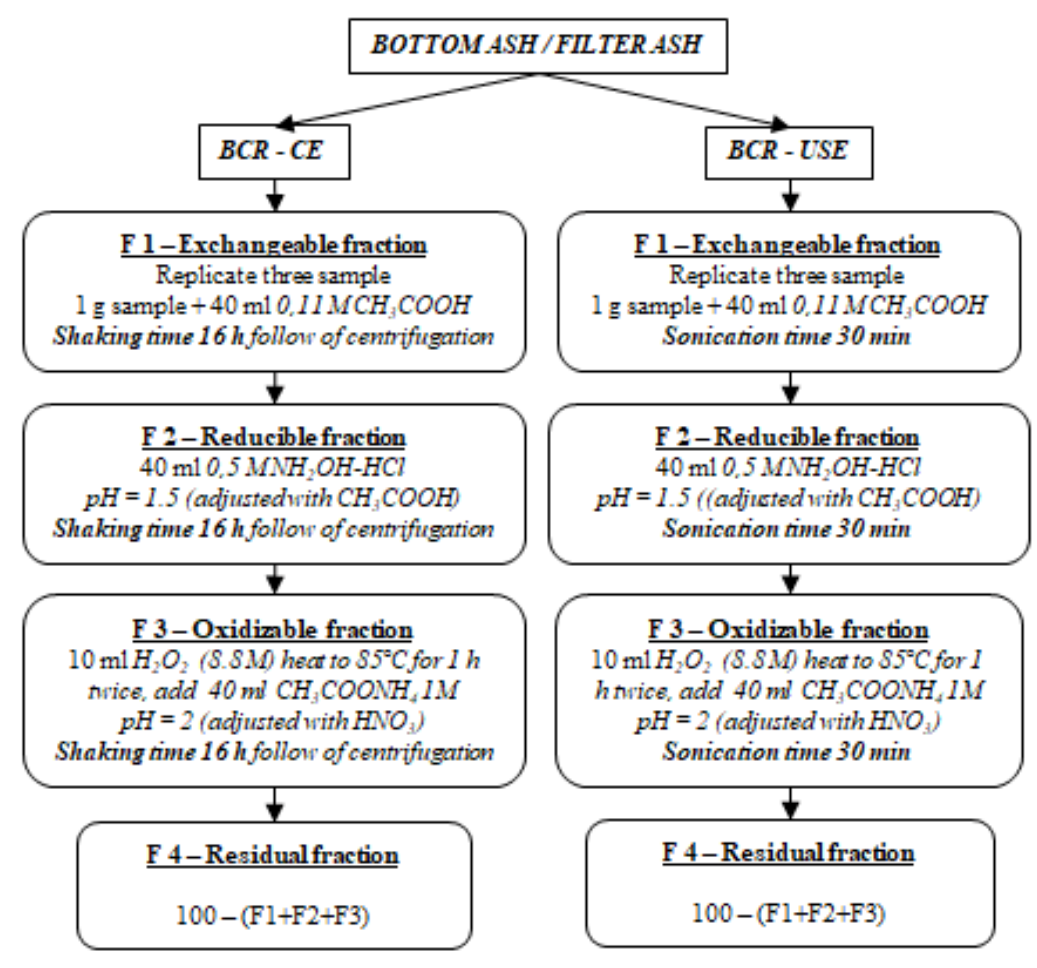

Scheme 1. Flow scheme for metallic fractions determination in ash samples

literature, a number of ash were studied on a particle size range from $\leq 38 \mu \mathrm{m}$ to $500 \mu \mathrm{m}$ [22]. In our study, the ash samples were sieved and the particle size less than $100 \mathrm{im}$ was retain in order to assess total content and chemical fractions of the metals.

For determination of total metal content, $1 \mathrm{~g}$ of each ash sample was dissolved in a mixture of concentrated acids (9.5 $\mathrm{mL} \mathrm{HNO}, 65 \%$ and $0.5 \mathrm{~mL} \mathrm{HF}$ ). The samples were mineralized in Ethos UP Milestone Microwave equipment at $220^{\circ} \mathrm{C}$ and $1500 \mathrm{~W}$ power.

Leaching behavior was tested according to Romanian Order No. 95/2005 [23], the batch leaching test being in accordance with in force regulation [24]. The test was performed at a ratio of 10 tol between the leachate (distillated water) and the sample.

\section{The evaluation of metallic fractions by sequential extraction procedure}

$B C R$ sequential extraction procedure classic (BCR-CE) and modified BCR (BCR-USE) were used for the extraction of metal fractions, such as: exchangeable, reducible, oxidizable and residual fraction. Modified BCR method reduce the extraction time from 16 hours to 30 min using ultrasonic extraction, a method which is commonly applied for the extraction of metallic fractions from soils and sediments [20].

Scheme 1 shows the steps used in both methods for sequential chemical extraction procedures.

Determination of elements: $\mathrm{Cr}, \mathrm{Ni}, \mathrm{Cu}, \mathrm{Zn}, \mathrm{Pb}$ was performed using atomic absorption spectrometry technique (Flame-AAS) using a PinAAcle 900T Perkin Elmer equipment, while As and $\mathrm{Cd}$ were analyzed the inductively coupled plasma mass spectrometry (ICP-MS) on an Aurora M90 Bruker spectrometer. All the chemicals were of analytical reagent grade (Merck quality).
Toxicity characteristic leaching procedure (TCLP)

Toxicity characteristic leaching procedure (TCLP) was used to assess the toxic characteristic of the metals in the analyzed ashes [21]. This procedure consists in extraction of leachable metals from ash using glacial acetic acid at controlled $p \mathrm{H}$ : $\mathrm{pH}$ of $4.93 \pm 0.05$ for extraction fluid \#1 or $p H$ of $2.88 \pm 0.05$ for extraction fluid \#2, according to initial $\mathrm{pH}$ of the ash sample. When the sample has a $\mathrm{pH}$ value less than 5 , for TCLP assessment is used the fluid extraction $\# 1$, while the $\mathrm{pH}$ value of the sample is higher than 5 is used fluid extraction \#2. In our case, because bottom and filter ashes has a pH value higher than $5 \mathrm{pH}$ units, fluid extraction \#2 was used as follows: $1 \mathrm{~g}$ of the sample with $20 \mathrm{~mL}$ of $\mathrm{CH}_{3} \mathrm{COOH}$ at $2.89 \mathrm{pH}$ units was placed in a rotating system for $18 \mathrm{~h}$ at $30 \mathrm{rpm}$. After the completion of the extraction, the leachate was filtered through Whatman $\mathrm{GF} / \mathrm{C}$ glass filter paper $(0.45 \mu \mathrm{m})$, acidified with $5 \% \mathrm{HNO}_{3}$ and analyzed by ICP-MS techniques.

\section{Results and discussions}

Total concentrations of metals in solid samples and leaching test

Table 2 shows the results obtained for total metal concentrations in the solid samples, respectively bottom and filter ashes.

For heavy metal load there is a significant difference between bottom and filter ashes (table 2). For example cadmium, which is part of the priority dangerous substances category, its concentration in filter ash exceeds 30 times its concentration in bottom ash in both analyzed batches. The metal with the highest concentrations in both bottom and filter ashes is $\mathrm{Zn}$ with values ranging from 1174 $\mathrm{mg} / \mathrm{kg}$ dry matter (dm) to $28630 \mathrm{mg} / \mathrm{kg} \mathrm{dm}$.

Table 2

TOTAL CONTENT OF METALS IN ASH SAMPLES $(\mathrm{mg} / \mathrm{kg} \mathrm{dm}$ )

\begin{tabular}{|c|c|c|c|c|c|c|c|c|c|}
\hline Batch & Samples & $\mathrm{pH}$ & $\mathrm{Cr}$ & $\mathrm{Ni}$ & $\mathrm{Cu}$ & $\mathrm{Zn}$ & $\mathrm{Pb}$ & As & $\mathrm{Cd}$ \\
\hline \multirow{2}{*}{1} & BAl & 6.6 & 24.4 & 131 & 224 & 1174 & 1823 & 1.53 & 2.67 \\
\hline & FAl & 10.1 & 2692 & 575 & 3432 & 16500 & 10218 & 24.9 & 81 \\
\hline \multirow{2}{*}{2} & BA2 & 6.5 & 243 & 70.8 & 435 & 2570 & 529 & 1.65 & 3.38 \\
\hline & FA2 & 10.5 & 3860 & 682 & 2950 & 28630 & 15639 & 32.6 & 130 \\
\hline
\end{tabular}




\begin{tabular}{|c|c|c|c|c|c|c|c|c|}
\hline \multirow{3}{*}{ Metal } & \multicolumn{4}{|c|}{ Ash samples } & \multicolumn{3}{|c|}{ MAV* $^{*}$} & \multirow{10}{*}{$\begin{array}{c}\text { Table } 3 \\
\text { LEACHING } \\
\text { TESTS - } \\
\text { CONTENT OF } \\
\text { METALS } \\
(\mathrm{mg} / \mathrm{kg} \mathrm{dm})\end{array}$} \\
\hline & \multicolumn{2}{|c|}{ Batch 1 } & \multicolumn{2}{|c|}{ Batch 2} & \multirow{2}{*}{ Inert } & \multirow{2}{*}{ Non hazardous } & \multirow{2}{*}{ Hazardous } & \\
\hline & BAl & FAl & $\overline{\mathrm{BA} 2}$ & FA2 & & & & \\
\hline $\mathrm{Cr}$ & 0.23 & 65.1 & 0.45 & $\underline{82.6}$ & 0.5 & 10 & 70 & \\
\hline $\mathrm{Ni}$ & 1.09 & 21.7 & 0.82 & $\overline{35.3}$ & 0.4 & 10 & 40 & \\
\hline $\mathrm{Cu}$ & 1.56 & 74.3 & 3.21 & 66.8 & 2 & 50 & 100 & \\
\hline $\mathbf{Z n}$ & 21.8 & $\underline{527}$ & 25.6 & 973 & 4 & 50 & 200 & \\
\hline $\mathrm{Pb}$ & 8.90 & $\underline{372}$ & 5.43 & 421 & 0.5 & 10 & 50 & \\
\hline As & 0.04 & $\overline{0.92}$ & 0.06 & $\overline{0.84}$ & 0.5 & 2 & 25 & \\
\hline $\mathrm{Cd}$ & 0.06 & 0.38 & 0.09 & 0.57 & 0.04 & 1 & 5 & \\
\hline
\end{tabular}

Comparing the results obtained in the two batches, it can be observed that there is some differences between the concentration of metals from batch 1 and batch 2 . For the majority analyzed metals the concentrations in batch 2 was higher than concentrations in batch 1 .

The experimental data obtained for leaching tests are presented in Table 3.

In order to establish what kind of landfill will be used for waste disposal, the obtained results were compared with MAV (table 3) and it was found that:
- BA1 and BA2 wastes can be stored in non-dangerous waste landfills;

- FA1 and FA2 wastes cannot be stored on any kind of landfill without a prior treatment, the concentrations for $\mathrm{Cr}$, $\mathrm{Zn}$ and $\mathrm{Pb}$ exceed the maximum admissible values for hazardous waste landfills.

Distribution of metals in ash samples chemical fractions

The obtained results from sequential chemical extraction procedures indicate that BCR-CE method has higher extraction percentages than BCR-USE method (tables 4 and 5).

Table 4

TOTAL CONTENT OF METALS BY BCR CLASSIC METHOD (BCR-CE) (mg/kg dm)

\begin{tabular}{|c|c|c|c|c|c|c|c|c|}
\hline Fractions & Samples & $\mathrm{Cr}$ & $\mathrm{Ni}$ & $\mathrm{Cu}$ & $\mathbf{Z n}$ & $\mathrm{Pb}$ & As & $\mathbf{C d}$ \\
\hline \multirow{2}{*}{ F 1} & $\overline{B A 1}$ & $1.60 \pm 0.02$ & $5.00 \pm 0.08$ & $35.6 \pm 0.39$ & $185 \pm 2.03$ & $126 \pm 1.39$ & $0.10 \pm 0.01$ & $0.20 \pm 0.01$ \\
\hline & BA2 & $12.7 \pm 0.19$ & $10.4 \pm 0.16$ & $56.9 \pm 0.63$ & $180 \pm 1.98$ & $60.9 \pm 0.67$ & $0.15 \pm 0.01$ & $0.59 \pm 0.04$ \\
\hline \multirow{2}{*}{ F 2} & $\overline{B A 1}$ & $8.50 \pm 0.13$ & $43.2 \pm 0.65$ & $90.5 \pm 0.99$ & $743 \pm 8.17$ & $523 \pm 5.75$ & $0.30 \pm 0.02$ & $1.10 \pm 0.07$ \\
\hline & BA2 & $123 \pm 1.85$ & $29.3 \pm 0.43$ & $200 \pm 2.20$ & $1200 \pm 13.2$ & $37.8 \pm 0.42$ & $0.42 \pm 0.03$ & $0.87 \pm 0.06$ \\
\hline \multirow{2}{*}{ F 3} & BA1 & $6.20 \pm 0.09$ & $22.6 \pm 0.33$ & $56.1 \pm 0.61$ & $139 \pm 1.53$ & $382 \pm 4.20$ & $0.30 \pm 0.02$ & $0.50 \pm 0.04$ \\
\hline & $\overline{B A 2}$ & $49.6 \pm 0.74$ & $23.2 \pm 0.35$ & $127 \pm 1.39$ & $1095 \pm 12.0$ & $357 \pm 3.92$ & $0.28 \pm 0.02$ & $0.93 \pm 0.06$ \\
\hline \multirow{2}{*}{ F 4} & BA1 & $8.20 \pm 0.12$ & $60.3 \pm 0.90$ & $41.9 \pm 0.46$ & $107 \pm 1.18$ & $792 \pm 8.71$ & $0.80 \pm 0.07$ & $0.80 \pm 0.05$ \\
\hline & $\overline{B A 2}$ & $57.8 \pm 0.87$ & $7.96 \pm 0.11$ & $51.1 \pm 0.56$ & $95.0 \pm 1.05$ & $73.3 \pm 0.81$ & $0.80 \pm 0.07$ & $0.99 \pm 0.06$ \\
\hline \multirow{2}{*}{ F 1} & $F A 1$ & $265 \pm 3.39$ & $77.3 \pm 1.16$ & $460 \pm 5.06$ & $856 \pm 9.14$ & $621 \pm 6.83$ & $2.20 \pm 0.18$ & $5.46 \pm 0.38$ \\
\hline & $F A 2$ & $412 \pm 6.18$ & $69.8 \pm 1.04$ & $320 \pm 3.52$ & $1259 \pm 13.8$ & $644 \pm 7.08$ & $2.08 \pm 0.17$ & $6.82 \pm 0.47$ \\
\hline \multirow{2}{*}{ F 2} & $F A 1$ & $1514 \pm 22.7$ & $305 \pm 4.57$ & $1389 \pm 15.3$ & $9560 \pm 105$ & $5482 \pm 60.3$ & $6.45 \pm 0.58$ & $13.8 \pm 0.96$ \\
\hline & $F A 2$ & $1726 \pm 25.9$ & $435 \pm 6.52$ & $1312 \pm 14.4$ & $16560 \pm 182$ & $6896 \pm 75.8$ & $8.65 \pm 0.77$ & $39.4 \pm 2.75$ \\
\hline \multirow{2}{*}{ F 3} & FA1 & $865 \pm 12.9$ & $123 \pm 1.84$ & $786 \pm 8.64$ & $5423 \pm 59.6$ & $3430 \pm 37.7$ & $3.56 \pm 0.32$ & $35.4 \pm 2.47$ \\
\hline & $F A 2$ & $1064 \pm 15.9$ & $86.9 \pm 1.30$ & $896 \pm 9.85$ & $9432 \pm 104$ & $4752 \pm 52.3$ & $5.92 \pm 0.53$ & $62.8 \pm 4.39$ \\
\hline \multirow{2}{*}{ F 4} & FA1 & $48.0 \pm 0.72$ & $69.7 \pm 1.04$ & $797 \pm 8.76$ & $661 \pm 7.27$ & $685 \pm 7.53$ & $12.7 \pm 0.75$ & $26.3 \pm 1.84$ \\
\hline & $F A 2$ & $658 \pm 9.87$ & $90.3 \pm 1.35$ & $422 \pm 4.64$ & $1379 \pm 15.1$ & $3347 \pm 36.8$ & $15.6 \pm 0.96$ & $21.0 \pm 1.47$ \\
\hline
\end{tabular}

F1 - exchangeable fraction; F2 - reducible fraction; F3 - oxidizable fraction; F 4 = Total content - (F1+F2+F3)

Table 5

TOTAL CONTENT OF METALS BY BCR MODIFIED METHOD (BCR-USE) (mg/kg dm)

\begin{tabular}{|c|c|c|c|c|c|c|c|c|}
\hline Fractions & Samples & $\mathrm{Cr}$ & $\mathbf{N i}$ & $\mathrm{Cu}$ & Zn & $\mathrm{Pb}$ & As & $\mathrm{Cd}$ \\
\hline \multirow{2}{*}{ F 1} & $\overline{B A 1}$ & $1.20 \pm 0.02$ & $5.28 \pm 0.08$ & $33.8 \pm 0.37$ & $156 \pm 1.71$ & $119 \pm 1.31$ & $0.12 \pm 0.01$ & $0.25 \pm 0.01$ \\
\hline & $B A 2$ & $11.8 \pm 0.18$ & $8.40 \pm 0.13$ & $40.6 \pm 0.45$ & $158 \pm 1.74$ & $58.4 \pm 0.64$ & $0.11 \pm 0.01$ & $0.42 \pm 0.02$ \\
\hline \multirow{2}{*}{ F 2} & $\overline{B A 1}$ & $4.26 \pm 0.06$ & $40.9 \pm 0.61$ & $65.6 \pm 0.72$ & $558 \pm 6.14$ & $426 \pm 4.68$ & $0.26 \pm 0.02$ & $1.09 \pm 0.07$ \\
\hline & BA2 & $98.0 \pm 1.47$ & $25.9 \pm 0.39$ & $180 \pm 1.98$ & $968 \pm 10.6$ & $29.5 \pm 0.32$ & $0.49 \pm 0.04$ & $0.46 \pm 0.03$ \\
\hline \multirow{2}{*}{ F 3} & $\overline{B A 1}$ & $4.15 \pm 0.06$ & $20.1 \pm 0.30$ & $40.3 \pm 0.44$ & $145 \pm 1.59$ & $316 \pm 3.47$ & $0.44 \pm 0.03$ & $0.32 \pm 0.02$ \\
\hline & $B A 2$ & $46.9 \pm 0.7$ & $21.6 \pm 0.32$ & $96.0 \pm 1.05$ & $1123 \pm 12.4$ & $328 \pm 3.60$ & $0.21 \pm 0.01$ & $0.69 \pm 0.05$ \\
\hline \multirow{2}{*}{ F 4} & BA1 & $14.8 \pm 0.22$ & $64.7 \pm 0.97$ & $84.3 \pm 0.92$ & $315 \pm 3.46$ & $962 \pm 10.5$ & $0.83 \pm 0.07$ & $1.01 \pm 0.07$ \\
\hline & $\overline{B A 2}$ & $86.4 \pm 1.30$ & $14.9 \pm 0.22$ & $118 \pm 1.29$ & $321 \pm 3.53$ & $113 \pm 1.24$ & $0.84 \pm 0.07$ & $1.81 \pm 0.13$ \\
\hline & & & & & & & & \\
\hline \multirow{2}{*}{ F 1} & FA1 & $189 \pm 2.84$ & $70.4 \pm 1.06$ & $382 \pm 4.20$ & $820 \pm 9.02$ & $567 \pm 6.24$ & $2.69 \pm 0.24$ & $4.18 \pm 0.29$ \\
\hline & $F A 2$ & $395 \pm 5.93$ & $70.9 \pm 1.06$ & $349 \pm 3.84$ & $1187 \pm 13.0$ & $598 \pm 6.58$ & $1.95 \pm 0.17$ & $5.46 \pm 0.38$ \\
\hline \multirow{2}{*}{ F 2} & $F A 1$ & $1124 \pm 16.9$ & $292 \pm 4.38$ & $1286 \pm 14.1$ & $8992 \pm 98.9$ & $3862 \pm 42.4$ & $5.44 \pm 0.48$ & $10.7 \pm 0.75$ \\
\hline & $F A 2$ & $1206 \pm 18.1$ & $389 \pm 5.83$ & $1220 \pm 13.4$ & $15983 \pm 176$ & $6063 \pm 66.7$ & $6.48 \pm 0.58$ & $40.5 \pm 2.83$ \\
\hline \multirow{2}{*}{ F 3} & $F A 1$ & $786 \pm 11.8$ & $114 \pm 1.71$ & $644 \pm 7.08$ & $4830 \pm 53.1$ & $2318 \pm 25.4$ & $2.81=0.25$ & $29.8 \pm 2.08$ \\
\hline & $F A 2$ & $851=12.8$ & $72.0 \pm 1.08$ & $798 \pm 8.77$ & $8793 \pm 96.7$ & $3876 \pm 42.6$ & $4.92 \pm 0.44$ & $55.8 \pm 3.90$ \\
\hline \multirow{2}{*}{ F 4} & FA1 & $593 \pm 8.89$ & $98.7 \pm 1.48$ & $1120 \pm 12.3$ & $1858 \pm 20.4$ & $3440 \pm 37.8$ & $13.9 \pm 0.88$ & $36.3 \pm 2.54$ \\
\hline & $F A 2$ & $1408 \pm 21.1$ & $150 \pm 2.25$ & $583 \pm 6.41$ & $2667 \pm 29.4$ & $5102 \pm 56.1$ & $19.3 \pm 0.93$ & $28.2 \pm 1.97$ \\
\hline
\end{tabular}

F1 - exchangeable fraction; F2 - reducible fraction; F3 - oxidizable fraction; F 4 = Total content - (F1+F2+F3) 
In order to be use in such studies, BCR-USE method needs to be improved by optimizing the extraction time, $\mathrm{pH}$ value or the report between solution and solid sample. Repartition of metals in ash chemical fractions was performed only for the results obtained with BCR-CE method. Distribution of heavy metal in fractions for bottom and filter ashes is shown in Figures 1-4.

Bottom ash from batch 1 - BA1

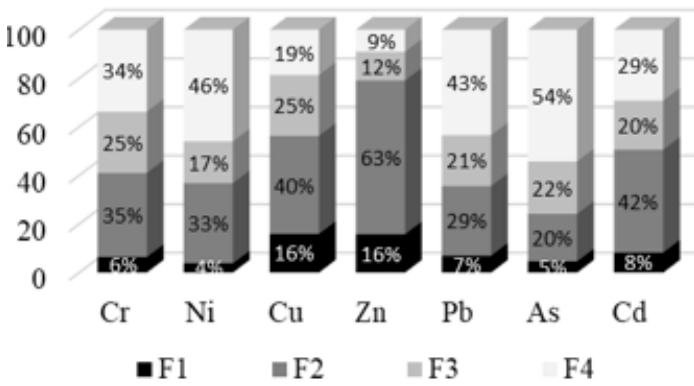

Fig 1. Distribution of heavy metal fractions in BA1

(F1- exchangeable forms; F2- bound to iron and manganese oxides; F3 - bound to organic matter; F4 - bound to crystalline iron oxides and residual)

Bottom ash from batch 2 - BA2

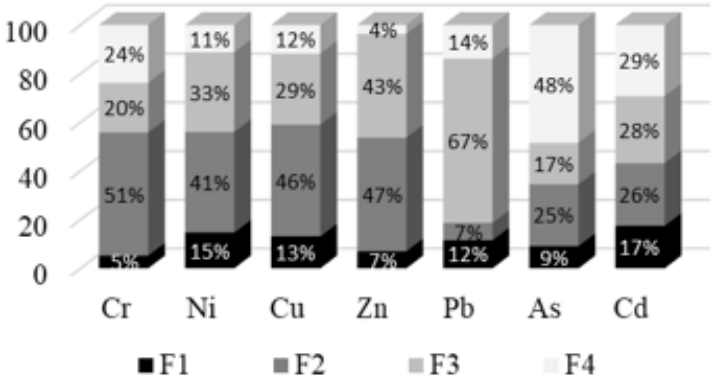

Fig 2. Distribution of heavy metal fractions in BA2

(F1- exchangeable forms; F2- bound to iron and manganese oxides; F3 - bound to organic matter; F4 - bound to crystalline iron oxides and residual)

Filter ash from batch 1 - FA1

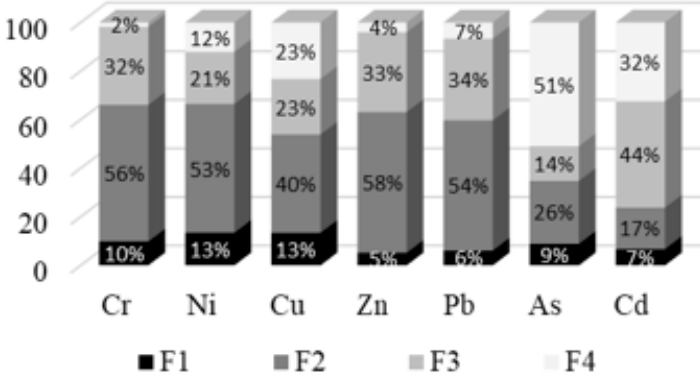

Fig 3. Distribution of heavy metal fractions in FA1

(F1- exchangeable forms; F2- bound to iron and manganese oxides; F3 - bound to organic matter; F4 - bound to crystalline iron oxides and residual)

Filter ash from batch 2 - FA2

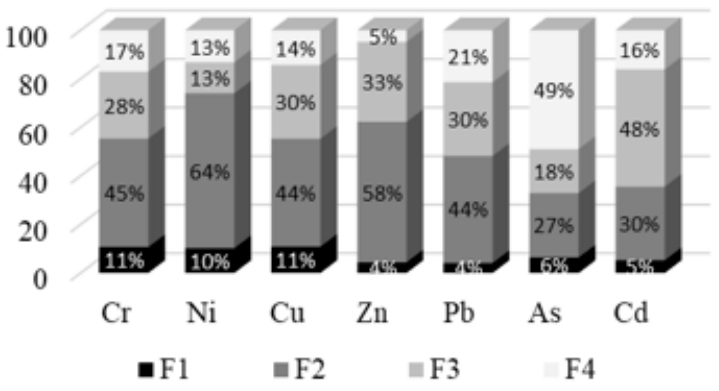

Fig 4. Distribution of heavy metal fractions in FA2

(F1- exchangeable forms; F2- bound to iron and manganese oxides; F3 - bound to organic matter; F4 - bound to crystalline
The importance of sequential extraction studies is their ability to estimate the capacity of metals to become available to the environment. Thus, from F2, the metals can pass into the F1 fraction in a short time if there are accidental spills of oxidant/ reducers on the landfill to favor this process. The shift from F3 to F1 can be made much harder under the influence of climatic conditions, in decades, while metals captured in F4 are not available to the environment [26].

Regarding BA ash samples, it can be said that $\mathrm{As}, \mathrm{Cd}$ and Ni are mainly bounded to F2, F3 and F4 fractions, small quantity being in exchangeable forms, without environmental impact. Considering those mentioned in the previous paragraph, the amount of $\mathrm{Zn}$ in F1 and F2 fractions may pose a potential environmental hazard, representing more than $1000 \mathrm{mg} / \mathrm{kg} \mathrm{dm}$. In terms of $\mathrm{Cr}$ content, small quantify are bounded in exchangeable form, buta problem could be in BA2 high percentage (51\%) and concentration from F2 fraction ( $123 \mathrm{mg} / \mathrm{kg} \mathrm{dm}$ ). Same situation is noted in the Cu case, where around $15 \%$ is bound in exchangeable forms and additional $40-50 \%$ in F2 fraction, representing more than $100 \mathrm{mg} / \mathrm{kg} \mathrm{dm}$. Instead, in the case of lead, there may be a certain problem in the case of storage if we also consider these studies because high concentrations of $\mathrm{Pb}$ were bounded in $\mathrm{F} 1$ and $\mathrm{F} 2$ fractions, mainly in BA1.

During combustion, high amounts of metals condense at low temperature through the volatile compounds formation which are transported with unburned carbon in filter ash [22]. Therefore, the metals accumulated in the filter ash are much higher than in the bottom ash.

In filter ash, $\mathrm{Zn}$ and $\mathrm{Pb}$ are linked to $\mathrm{F} 1$ fraction in high concentrations, representing $1,259 \mathrm{mg} / \mathrm{kg} \mathrm{dm}$ for $\mathrm{Zn}$ and $644 \mathrm{mg} / \mathrm{kg} \mathrm{dm}$ for Pb, with a potential environmental hazard. The amounts of these metals exceed $40 \%$ of the total content in F2 fractions, content of zinc representing more than $16,000 \mathrm{mg} / \mathrm{kg}$ dm in FA2, respectively 9,000 $\mathrm{mg} / \mathrm{kg} \mathrm{dm}$ in FAl with a strong pollution potential in case of storage. The same situation is also noted for $\mathrm{Cr}$ and $\mathrm{Cu}$, hundreds of $\mathrm{mg} / \mathrm{kg}$ being bound in F1 fraction. Also, more than $1300 \mathrm{mg} / \mathrm{kg} \mathrm{dm}$ are founded in the F2 fraction both in $\mathrm{FAl}$ and $\mathrm{FA} 2$. Regarding $\mathrm{Ni}$, small quantity is bounded in the exchangeable fraction, more than $50 \%$ of the total content being in iron and manganese oxides in concentrations higher than $300 \mathrm{mg} / \mathrm{kg} \mathrm{dm}$, for both samples. The relatively slight pass of the metal from F2 into the F1 fraction may induce a potential environmental hazard. Important quantities of As $(8.65 \mathrm{mg} / \mathrm{kg} \mathrm{dm})$ and $\mathrm{Cd}(39.4 \mathrm{mg} / \mathrm{kg} \mathrm{dm}$ ) are linked in F1 and F2 fractions, being necessary an important attention to storage, due to the high toxicity of these metals.

\section{Toxicity Characteristic Leaching Procedure (TCLP)}

In table 6 , the results from the toxicity characteristic leaching procedure are compared with the values reported by US EPA Standard [25].

It was observed that $\mathrm{Pb}$ exceeds four times the regulated value in the liquid filtrate from filter ashes. Concentrations of the other analyzed metals are below the regulated values with the exception of Cr in FA2 sample.

Comparing the results in $\mathrm{mg} / \mathrm{kg}$ from TCLP test with the values from bioavailability mobile fraction (F1), it can be observed for both ashes that results from F1 are higher than TCLP test results (figs. 5, 6).

In conclusion, it can be noticed that while in bottom ash the metal concentrations are in the range of tens to 180 $\mathrm{mg} / \mathrm{kg}$, in the case of filtered ash, the concentrations are from hundreds up to a maximum of $1300 \mathrm{mg} / \mathrm{kg}$. Due to the high content of $\mathrm{Cu}, \mathrm{Cr}, \mathrm{Pb}$ and $\mathrm{Zn}$ in exchangeable forms 
Table 6

THE LEACHABLE HEAVY METALS IN BOTTOM AND FILTER ASHES BY TCLP TEST

\begin{tabular}{|c|c|c|c|c|c|}
\hline \multirow{2}{*}{ Sample } & \multicolumn{4}{|c|}{ TCLP (mg/L) } & \multicolumn{2}{c|}{ Filter ash } & \multirow{2}{*}{$\begin{array}{c}\text { TCLP } \\
\text { US EPA } \\
\end{array}$} \\
\cline { 2 - 6 } & BAl & BA2 & FAl & FA2 & Standard (mg/L) [25] \\
\hline $\mathbf{C r}$ & 0.048 & 0.196 & 4.06 & $\mathbf{6 . 3 9}$ & 5 \\
\hline $\mathbf{N i}$ & 0.163 & 0.269 & 2.84 & 2.46 & 100 \\
\hline $\mathbf{C u}$ & 1.48 & 2.38 & 18.8 & 14.3 & 100 \\
\hline $\mathbf{Z n}$ & 5.65 & 6.35 & 32.1 & 47.1 & - \\
\hline $\mathbf{P b}$ & 4.13 & 2.48 & $\mathbf{2 1 . 2}$ & $\mathbf{2 4 . 3}$ & 5 \\
\hline As & 0.003 & 0.005 & 0.077 & 0.070 & 5 \\
\hline $\mathbf{C d}$ & 0.006 & 0.017 & 0.263 & 0.260 & 1 \\
\hline
\end{tabular}

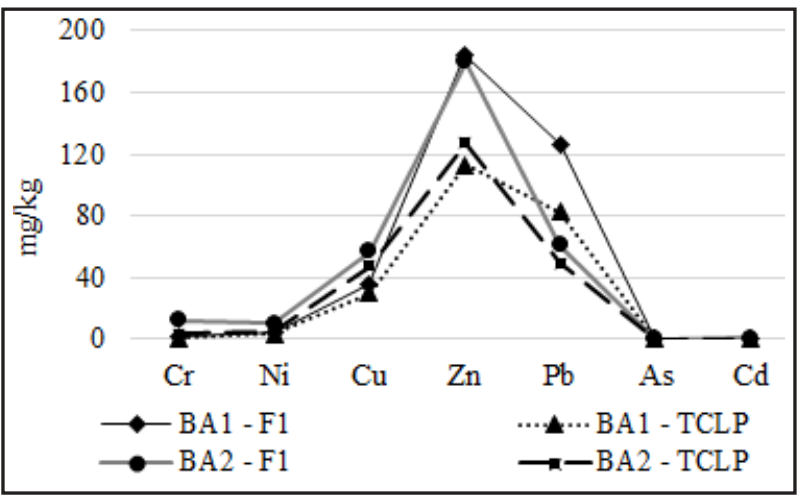

Fig 5. Comparative results obtained in F1 and TCLP for bottom

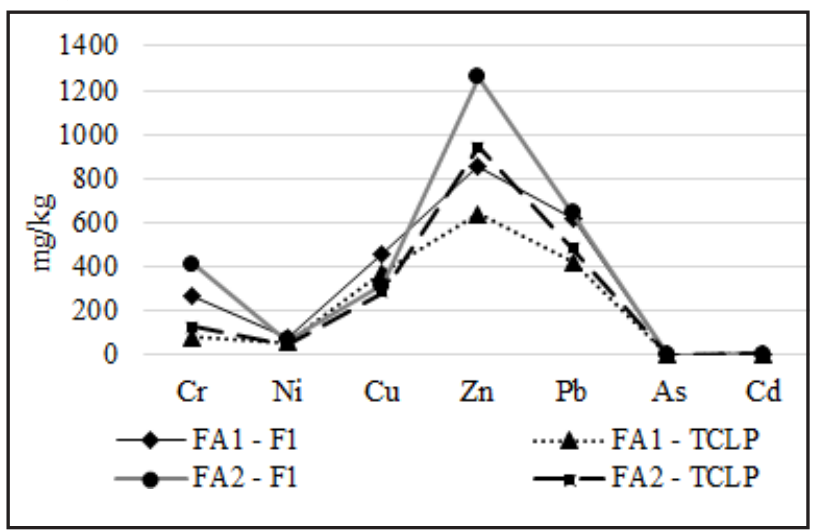

Fig 6. Comparative results obtained in F1 and TCLP for filter ash

of filter ashes, a special attention should be considered to the management of this waste, in order to avoid heavy metals dispersion in environment components (air, soil, surface water).

\section{Conclusions}

Two different types of ash (bottom and filter ash) from the incineration of medical waste containing toxic metals were subjected to leaching and sequential extraction tests in order to estimate the storage risk.

The sequential extraction procedures according to BCRCE method was applied and the metal distribution along the ash compounds in operationally defined fractions, such as: F1- exchangeable forms, F2-iron and manganese oxides, F3-organic matter, F4-crystalline iron oxides and residual form, were determined.

Short-term bottom ash storage is safer than filtered ash, where high content of metals in the $F 1$ and $F 2$ fractions, representing more than $16,000 \mathrm{mg} / \mathrm{kg} \mathrm{dm} \mathrm{Zn,} 7,000 \mathrm{mg} /$ $\mathrm{kg} \mathrm{dm} \mathrm{Pb}, 1,400 \mathrm{mg} / \mathrm{kg} \mathrm{dm} \mathrm{Cu}$ and $1,800 \mathrm{mg} / \mathrm{kg} \mathrm{dm} \mathrm{Cr}$ were determined. Both investigated filtered ashes cannot be stored without a prior treatment, this conclusion being confirmed also by the TCLP and the leaching tests.
However, long-term storage for both types of ash can induce a potential environmental hazard, due to the environmental conditions, the morphological changes of the waste and the accumulation of metals in fractions F1 and F2.

Acknowledgements: This work was carried out through the Program Nucleu PRO MEDIND, financed by the Ministry of Research and Innovation, project code: PN 18050401.

\section{References}

1. XIAO, Z., YUAN, X., Li, H., JIANG, L., LENG, L., CHEN, X., ZENG, G., Li, F., CAO, L., Sci. Total Environ., 536, 2015, p. 774-783

2. NECULESCU, C., IONITA, L., BUCUR, E., J. Environ. Prot. Ecol., 9, no. 1, 2008, p.1-14

3.COZEA, A., BUCUR, E., LEHR, C.B., PASCU, L.F., TANASE, G., Rev. Chim.(Bucharest), 64, no.11, 2018, p. 4138-4140

4. CONSTANTIN, M.A., BATRINESCU, G., CRISTEA, I., BADESCU, V.R., $19^{\text {th }}$ International Symposium The Environment and the Industry, 2016, p. 409-415

5. TESSIER, A., CAMPBELL, P.G., BISSON, M., Anal. Chem., 51, 1979, p.844-851

6. NYAMANGARA, J., Agric. Ecosyst. Environ., 69, 1998, p. 135-141 7. BRUDER-HUBSCHER V., LAGARDE, F., LEROY, M., COUGHANOWR, C., ENGUEHARD, F., Anal. Chim. Acta, vol. 451, no. 2, 2002, p. 285-295 8. VASILE, G.G., POPA, D.E., BULEANDRA, M., DAVID, I.G., Environ. Monit. Assess., 190, no.10, 2018, p. 1-12

9. VASILE, G.G., CRUCERU, L., PETRE, J., TANASE, I.G., Rev. Chim.(Bucharest), 58, no.12, 2007, p. 1332-1334

10. DINU, C., UNGUREANU, E.M., VASILE, G.G., KIM, L., IONESCU, I., ENE, C., SIMION, M., Rev. Chim.(Bucharest), 69, no.1, 2018, p. 14-20 11. DINU, C., UNGUREANU, E.M., VASILE, G.G., KIM, L., PASCU, L.F., SIMION, M., Rev. Chim.(Bucharest), 69, no.11, 2018, p. 4141-4147

12. RAURET, G., LOPEZ-SANCHEZ, J.F., SAHUQUILLO, A., RUBIO, R., DAVIDSON, C., URE, A., QUEVAUVILLER, P., J. Environ. Monit., 1, no. 1,1999, p. 57-61

13. KIM, L., VASILE, G.G., STANESCU, B., DINU, C., ENE, C., Rev. Chim.(Bucharest), 67, no. 8, 2016, p. 1441-1446

14. IORDACHE, P.Z., SOMOGHI, V., SAVU, I., PETREA, N., MITRU, G., PETRE, R., DIONEZIE, B., ORDEANU, V., KIM, L., MUTIHAC, L., Optoelectron. Adv. Mat., 2, no. 8, 2008, p. 491-497

15. KIM, L., VASILE, G.G., STANESCU, B., CALINESCU, S., BATRINESCU, G, J. Environ. Prot. Ecol., 16, no. 4, 2015, p.1227-1236

16. RAJOR, A., XAXA, M., MEHTA, R., J. Environ. Manage., 108, 2012, p. 36-41

17. GIDARAKOS, E., PETRANTONAKI, M., ANASTASIADOU, K., SCHRAMM, K.W.,

J. Hazard. Mater., 172, 2009, p.935-942

18. HU, Y., ZHANG, P., Li, J., CHEN, D., J. Hazard. Mater., 299, 2015, p. 149-157

19. WEIBEL, G., EGGENBERGER, U., SCHLUMBERGER, S., MADER, U.K., Waste Manage., 62, 2017, p. 147-159 
20. ARAIN, M.B., KAZI, T.G., JAMALI, M.K., JALBANI, N., AFRIDI, H.I., BAIG, J.A.,

J. Hazard. Mater., 154, 2008, p. 998-1006

21.*** USEPA, 2004 - Tests methods for evaluating solid waste, Physical Chemical Methods, SW-846, Method 1311, US Environmental Protection Agency, Washington, DC, 2004, p. 1-7

22. SUKANDAR, S., YASUDA, K., TANAKA, M., AOYAMA, I., Environ. Pollut., 144, 2006, p. 726-735

23.*** ORDER 95/2005, The criteria for the acceptance and preliminary acceptance procedures for waste at storage and national list of waste accepted in each class of waste landfill, Official Monitor of Romania, Part 1, no. 194/8.
24.*** SR EN 12457:2-2003 - Waste characterization. Leaching. Conformity check for leaching granular waste and sludge. Part 2: One stage batch test at a solid-liquid ratio of $10 \mathrm{l} / \mathrm{kg}$ for materials with a particle size of less than $4 \mathrm{~mm}$ (without or with a reduction in size). Romanian Standard Association, 30p.

25. ZHAO, L., ZHANG, F.S., CHEN, M., LIU, Z., WU, D.B.J., J. Hazard. Mater., 173, no. 1-3, 2010, p 181-185.

26 Kim, R.Y., Yoon, J.K., Kim, T.S., Yang, J.E., Owens G., Kim, K.R., Environ. Geochem. Health, 37, no. 6, 2015, p.1041-1061.

$\overline{\text { Manuscript received: } 12.08 .2018}$ 